\title{
Pathogenicity of four Phytophthora species on kauri: in vitro and glasshouse trials
}

\author{
I.J. Horner and E.G. Hough \\ The New Zealand Institute for Plant \& Food Research Limited, Private Bag 1401, \\ Havelock North, New Zealand \\ Corresponding author: ian.horner@plantandfood.co.nz
}

\begin{abstract}
In kauri forest soils surveys, Phytophthora taxon Agathis (PTA), P. cinnamomi, P. multivora and P. cryptogea were detected frequently. In vitro and glasshouse studies determined that all four Phytophthora species produced lesions on excised kauri leaves and stems. Lesion advance was significantly slower with P. cinnamomi, P. multivora and P. cryptogea than with PTA. When 2-year-old kauri seedlings were trunk-inoculated, lesion spread was rapid with PTA, trunks were girdled, and all trees died within 4-6 weeks. Phytophthora cinnamomi, P. multivora and P. cryptogea produced substantially smaller lesions than PTA, no trees died, and plant growth was only slightly suppressed. Following soil inoculation with PTA, all kauri seedlings died within 10 weeks. There were no deaths following soil inoculation with P. cinnamomi, P. multivora or P. cryptogea, although feeder root damage was observed and the respective pathogens were re-isolated. Results suggest that PTA is an aggressive pathogen, and the other three species are weaker pathogens of kauri.
\end{abstract}

Keywords Phytophthora, kauri, pathogenicity.

\section{INTRODUCTION}

In soil surveys to determine the presence of Phytophthora taxon Agathis (PTA) in kauri (Agathis australis) forest soils, a number of other Phytophthora species have been detected frequently (Waipara et al. 2013). These include P. cinnamomi, P. multivora and $P$. cryptogea. Kauri is particularly susceptible to PTA (Beever et al. 2009, 2010) and P. cinnamomi has long been considered a pathogen of kauri (Podger \& Newhook 1971; Horner 1984; Johnston et al. 2003). Phytophthora cryptogea has a wide host range (Erwin \& Ribeiro 1996), including kauri (Newhook 1959), and in Australia, P. multivora has been described as a pathogen of a number of different tree and shrub species (Scott et al.
2009), but pathogenicity of these species on kauri has not been determined.

Interactions among these various Phytophthora species could be important in the health of kauri forests. However, their relative pathogenicity and importance are not known. Before investigating interactions, particularly how other Phytophthora species may influence tree responses to PTA attack, it is necessary to determine the potential pathogenicity of each species in isolation.

The current trials investigated the potential pathogenicity of four commonly isolated Phytophthora species on kauri seedlings and plant tissues in a series of in vitro and glasshouse assays. 
Table 1 Phytophthora isolates used in pathogenicity studies on kauri. Kauri soil is defined as soil/roots collected beneath diseased kauri trees.

\begin{tabular}{llll}
\hline Species & Isolate & Origin & Source \\
\hline P. cinnamomi & $\mathrm{H} 280$ & Kauri soil, Huia & PFR, Horner collection \\
P. cinnamomi & $\mathrm{H} 401$ & Kauri soil, Henderson & PFR, Horner collection \\
P. cryptogea & $\mathrm{H} 245$ & Kauri stump/soil, Clevedon & PFR, Horner collection \\
P. cryptogea & $\mathrm{H} 252$ & Kauri soil, Mission Bay & PFR, Horner collection \\
P. multivora & $\mathrm{H} 238$ & Kauri soil, Auckland & PFR, Horner collection \\
P. multivora & $\mathrm{H} 249$ & Kauri soil, Devonport & PFR, Horner collection \\
P. multivora & $\mathrm{H} 455$ & Kauri trunk canker (Culture 2851) & Dr Peter Scott, Scion \\
P. multivora & $\mathrm{H} 456$ & Kauri soil & Dr Peter Scott, Scion \\
P.t. Agathis (PTA) & $\mathrm{H} 261$ & Kauri soil, Auckland & PFR, Horner collection \\
P.t. Agathis (PTA) & $\mathrm{H} 382$ & Kauri soil, Titirangi & PFR, Horner collection \\
\hline
\end{tabular}

\section{MATERIALS AND METHODS}

\section{Phytophthora cultures}

All cultures used in the study were baited from soil/roots collected beneath diseased kauri trees or isolated directly from kauri tissue (Table 1). Cultures were grown on $\mathrm{V} 8$ agar $\left(200 \mathrm{ml}\right.$ V8 juice, $3 \mathrm{~g} \mathrm{CaCO}_{3}$, $15 \mathrm{~g}$ agar, $800 \mathrm{ml}$ distilled water) before use.

\section{Leaf assays}

Leaves were excised from two 2-year-old glasshouse-grown kauri seedlings, then placed, lower side up, on a moistened tissue on a plastic tray. Using a hypodermic needle, a small surface wound was made $0.5-1 \mathrm{~cm}$ from the base of each leaf, and a 3-mm diameter V8 agar plug colonised with the test Phytophthora culture was placed on top of the wound. Ten leaves, five from each of the two kauri trees, were inoculated for each test culture. Non-colonised V8 agar plugs were placed on a further ten wounded leaves as controls. Trays containing the inoculated leaves on moist tissues were then individually sealed in plastic bags and incubated on a laboratory bench at $20^{\circ} \mathrm{C}$. After 10 days, the distance of lesion spread from the margin of the agar plug was measured. Lesion measurement data were log transformed before analysis using ANOVA (Minitab16 ${ }^{\circledR}$ ).

\section{Twig assays}

Eleven branches were harvested from each of five 2-year-old glasshouse-grown kauri seedlings. Branches were trimmed to segments $15-25 \mathrm{~cm}$ long. A sterile scalpel was used to cut out a 3-mm section of bark on one side of the branch segment,
$2 \mathrm{~cm}$ from the base. A 3-mm diameter V8 agar plug colonised by the test Phytophthora, or a noncolonised plug as a control, was placed on each wound. For each of the ten Phytophthora isolates and agar control, one branch from each of the five trees was inoculated. Branches were placed in plastic bags containing a moistened paper towel, then sealed and incubated flat on the laboratory bench at $20^{\circ} \mathrm{C}$ for 18 days. After incubation, branches were cut into $1-\mathrm{cm}$ long pieces and plated onto Phytophthora-selective agar (PARPH - corn meal agar $13 \mathrm{~g} /$ litre, pimaricin $5 \mathrm{mg} /$ litre, sodium ampicillin $250 \mathrm{mg} /$ litre, rifamycin $10 \mathrm{mg} /$ litre, PCNB $66.7 \mathrm{mg} /$ litre, hymexazol $50 \mathrm{mg} /$ litre), ensuring the orientation of each segment was sequential to simplify subsequent scoring. After 2 and 3 days, Phytophthora-like colonies emerging from the twig segments were marked on the bottom of the plate. To confirm their identities, these colonies were checked under the microscope for characteristic Phytophthora hyphae or spores. The origin of each colony was estimated by retracing hyphal emergence points in each twig segment and the distance of spread from the inoculation point at the time of plating was determined. Data were log transformed and analysed using ANOVA (Minitab $16^{\circledR}$ ).

\section{Seedling assays - trunk inoculation}

Two-year-old kauri seedlings growing in potting mix in planter bags, obtained from the Scion nursery in Rotorua, were used for the trunk inoculation trial. A single oat grain colonised by the test Phytophthora was inserted into a small 
incision made $10 \mathrm{~cm}$ up the trunk of each tree. Wounds with oat grains were then bound with grafting tape. There were six replicate trees for each of the four Phytophthora species (PTA, P. cinnamomi, P. multivora and P. cryptogea) and six trees inoculated with uncolonised oat grains as controls. Trees were kept in a glasshouse maintained between 18 and $22^{\circ} \mathrm{C}$. Each tree was held in an individual aluminium tray to prevent water exchange between plants. Trees were kept well watered, but not flooded.

Tree health was monitored regularly for 4 months, and any signs of disease were noted. Trunk height increase was recorded and lesion expansion (upward and downward) on trunks was measured. Isolations were made from at least two lesion margins for each species, to determine whether lesions were associated with the inoculated Phytophthora species.

\section{Seedling assays - root inoculation}

The same cohort of kauri seedlings as above was used for the root inoculation trial. Inoculum was prepared as a slurry made from macerated mycelial mats (grown in V8 broth, $200 \mathrm{ml} \mathrm{V8}$ juice in $800 \mathrm{ml}$ distilled water) and from oat grains colonised by the various Phytophthora species. Ten millilitres of this slurry, containing mycelium, oospores, sporangia and zoospores was poured into each of two 7-mm diameter holes in the soil around the roots. A slurry of macerated sterile oat grains soaked in V8 broth was used for control trees. There were six replicate trees for each of the four Phytophthora species (PTA, P. cinnamomi, P. multivora and P. cryptogea) and six un-inoculated control trees. Each tree was held in an individual 9-cm deep plastic container to prevent water exchange between plants. During and for $24 \mathrm{~h}$ following inoculation, the water level in the container was held at $8 \mathrm{~cm}$ depth, approximately $2 / 3$ of the way up the soil in the planter bag. This effectively saturated the whole soil profile. After $24 \mathrm{~h}$, the containers were emptied and the soil was allowed to drain. Trees were kept in a glasshouse maintained between 18 and $22^{\circ} \mathrm{C}$. Trees were kept well watered, maintaining the water level at the bottom of containers between 0 and $2 \mathrm{~cm}$ depth. Tree health was monitored regularly and any signs of disease were noted. Trunk height increase was also recorded. After 4 months trees were harvested and soil was carefully removed from each root system. Roots were inspected and the amount of feeder root decay was scored on a $0-5$ scale, where $0=$ less than $5 \%$ root tip decay, $1=5-25 \%, 2=25-50 \%, 3=50-75 \%, 4=75-$ $99 \%$ root tip decay and $5=$ dead.

Individual feeder roots selected at random from each plant were surface-sterilised in 50\% ethanol and plated onto (PARPH) medium to detect the presence of the inoculated Phytophthora species within root tissue.

\section{RESULTS}

\section{Leaf and twig assays}

Summaries of data on pathogen spread on leaves are presented in Table 2. No lesions or diseased tissues were observed in leaves that were treated with the uninoculated agar plugs. In contrast, with all four Phytophthora species tested, diseased tissue was noted around the agar plug, with lesions advancing along the leaf. Lesion size after 10 days was substantially greater $(\mathrm{P}<0.001)$ in leaves inoculated with PTA than with any of the other Phytophthora species. For each of the four Phytophthora species, the pathogen was readily re-isolated from the lesion margin.

Summaries of mean Phytophthora spread within inoculated excised twigs are presented in Table 2. No lesions were observed around uninoculated agar plugs, and no Phytophthora emerged from plated twig portions of these uninoculated controls. Only minimal pathogen spread was noted in the twig tissue inoculated with P. cinnamomi, with slightly but significantly $(\mathrm{P}<0.05)$, more growth with P. multivora and P. cryptogea. Growth of PTA within twig tissue was significantly $(\mathrm{P}<0.001)$ greater than growth of any of the other Phytophthora species.

\section{Seedling assays - trunk inoculation}

Within 1 month of inoculation, all six PTAinoculated trees showed moderate to severe signs of decline, with wilting and browning of the canopy. Within 2 months, all these trees were dead. The canopies of all uninoculated control trees and all trees inoculated with Phytophthora species other than PTA remained healthy throughout the experiment, except for an occasional side 
Table 2 Mean rate of Phytophthora growth in excised kauri leaves or twigs inoculated with one of four Phytophthora species (P. cinnamomi, P. cryptogea, P. multivora or P. taxon Agathis). The extent of colonisation was assessed 10 and 18 days after inoculation of leaves and twigs, respectively. Letters in brackets indicate statistical significance groupings determined by Tukey's pairwise comparisons. Data not sharing a common letter are significantly different $(\mathrm{P}<0.05)$ from each other.

\begin{tabular}{lccc}
\hline Species & Isolate & $\begin{array}{c}\text { Leaf lesion advance } \\
(\mathrm{mm} / \text { day })\end{array}$ & $\begin{array}{c}\text { Twig lesion advance } \\
\text { (mm/day) }\end{array}$ \\
\hline Control & & $0.0(\mathrm{~A})$ & 0.0 (A) \\
P. cinnamomi & $\mathrm{H} 280$ & $0.33(\mathrm{~B})$ & 0.01 (A) \\
P. cinnamomi & $\mathrm{H} 401$ & $0.38(\mathrm{~B})$ & $0.06(\mathrm{AB})$ \\
P. cryptogea & $\mathrm{H} 245$ & $0.25(\mathrm{~B})$ & $0.23(\mathrm{BC})$ \\
P. cryptogea & $\mathrm{H} 252$ & $0.39(\mathrm{~B})$ & $0.75(\mathrm{C})$ \\
P. multivora & $\mathrm{H} 238$ & $1.11(\mathrm{~B})$ & $0.24(\mathrm{BC})$ \\
P. multivora & $\mathrm{H} 249$ & $0.42(\mathrm{~B})$ & $0.04(\mathrm{AB})$ \\
P. multivora & $\mathrm{H} 455$ & $0.58(\mathrm{~B})$ & $0.26(\mathrm{BC})$ \\
P. multivora & $\mathrm{H} 456$ & $0.66(\mathrm{~B})$ & $0.12(\mathrm{AB})$ \\
P. taxon Agathis (PTA) & $\mathrm{H} 261$ & $3.43(\mathrm{C})$ & 4.80 (D) \\
P. taxon Agathis (PTA) & $\mathrm{H} 382$ & $2.71(\mathrm{C})$ & 3.13 (D) \\
\hline
\end{tabular}

branch near the inoculation point. Plant height increase was greatest in untreated control plants (Table 3), but statistically the growth increment was not significantly different from that in plants inoculated with $P$. cinnamomi, $P$. multivora or P. cryptogea $(\mathrm{P}>0.05)$. There was no growth of plants trunk-inoculated with PTA, reflecting the rapid trunk girdling and decline of these plants.

Control trunks inoculated with an uncolonised oat grain did not develop lesions and in all cases either healed over the wound, or pushed out the oat grain. In contrast, lesions were observed spreading from Phytophthora inoculation points of almost all seedlings, although the extent of the lesions varied between the four species, and even between replicates of each species (Table 3). Average lesion extension was similar either upwards or downwards from the inoculation point for each species. Lesion growth following PTA inoculation was rapid and extensive. When the final assessments were made, all the PTA-inoculated trees were dead and dried out, and in many cases the lesion margin was ill defined and had to be estimated. In most cases an arbitrary measure of $100 \mathrm{~mm}$ was recorded, an underestimate of the actual extent. Compared with those of PTA, lesion extensions with the other species were considerably smaller and in no case did the lesion girdle the trunk in the 4-month period of the trial. For all four species, the appropriate Phytophthora species could be reisolated from lesion margins.

\section{Seedling assays - root inoculation}

When trees in planter bags were soil-inoculated with PTA, all trees died within 10 weeks. In contrast, all un-inoculated control trees and all trees soil-inoculated with $P$. cinnamomi, $P$. cryptogea or $P$. multivora appeared healthy, with no obvious above-ground symptoms.

Tree growth (trunk height increment) was similar in un-inoculated control trees and trees soil-inoculated with P. cinnamomi, P. cryptogea or P. multivora (Table 4). In contrast, trees soilinoculated with PTA grew only a very small amount before wilting and dying.

Root disease scores following soil inoculation are summarised in Table 4. In PTA-inoculated trees, all feeder and main roots were dead. With the other three Phytophthora species, root disease scores were higher than in the uninoculated controls, but significantly less than with PTA inoculation $(\mathrm{P}<0.001)$. Feeder root tip death was common with all inoculated species, but apart from PTA, root damage appeared to be confined to feeder roots, with no spread to the structural root system. All four species were readily re- 
Table 3 Kauri seedling height increment and lesion spread up or down from the inoculation point, measured 4 months after trunk inoculation with one of four Phytophthora species. Letters in brackets indicate statistical significance groupings determined by Tukey's pairwise comparisons. Data not sharing a common letter are significantly different $(\mathrm{P}<0.05)$ from each other.

\begin{tabular}{|c|c|c|c|}
\hline Species & Height increment $(\mathrm{cm})$ & Lesion up (mm) & Lesion down $(\mathrm{mm})$ \\
\hline Control & $21.1 \quad(\mathrm{~A})$ & $0.0 \quad(\mathrm{~A})$ & (A) \\
\hline P. cinnamomi & $14.6 \quad(\mathrm{~A})$ & 7.34 (B) & 8.29 (C) \\
\hline P. cryptogea & $16.5 \quad(\mathrm{~A})$ & $1.74(\mathrm{AB})$ & $2.62(\mathrm{BC})$ \\
\hline P. multivora & $14.6 \quad(\mathrm{~A})$ & $2.22(\mathrm{AB})$ & $1.32(\mathrm{AB})$ \\
\hline P. t. Agathis (PTA) & $0.0 \quad(\mathrm{~B})$ & $94.68 \quad(\mathrm{C})$ & $95.75 \quad(\mathrm{D})$ \\
\hline
\end{tabular}

isolated from surface-sterilised feeder roots, but only PTA was isolated from main roots, crowns and lower stems. Phytophthora cinnamomi and an unknown Phytophthora sp. were isolated at a very low frequency from un-inoculated controls and from other Phytophthora treatments. This reflects a low incidence of background contamination from the nursery where plants were sourced. At the start of the trial, material was screened and any that tested positive for Phytophthora spp. were discarded, but some must have passed through as false negatives. It is considered that this low incidence of background contamination has not compromised the trial, as disease arising from inoculation was still higher than in uninoculated controls (Table 4). But if more detailed studies are planned in the future, extreme care must be taken to ensure Phytophthora-free nursery material.

\section{DISCUSSION}

This study reinforces existing knowledge that PTA is an extremely aggressive pathogen of kauri. In all assays, the spread of PTA within kauri tissue, and the disease it caused, were far greater than those of $P$. cinnamomi, $P$. cryptogea or P. multivora. Nevertheless, each of these last three species should also be recognised as pathogens of kauri, even if their pathogenicity is significantly less than that of PTA.

The average growth rate of PTA isolate $\mathrm{H} 261$ was $3.4 \mathrm{~mm}$ /day on kauri leaves and $4.8 \mathrm{~mm}$ /day on stems. This is very similar to the $4.9 \mathrm{~mm}$ /day which this isolate grows on V8 agar at $20^{\circ} \mathrm{C}$, indicating that there is little innate resistance slowing down the growth of PTA within the kauri tissue. In contrast, the other three species grew much more slowly in kauri tissue that they do on V8 agar, suggesting their growth is inhibited within kauri tissue. It was also observed that there was a more distinct lesion boundary with P. cinnamomi, P. cryptogea and P. multivorainfected leaves, twigs or trunks, in contrast to PTA, where the lesion boundary was often diffuse and difficult to pinpoint. PTA was readily isolated from tissue beyond the externally visible lesion margin, but this was not the case with the other species.

The relative pathogenicities of $P$. cinnamomi, P. cryptogea and P. multivora are difficult to determine. All three species were able to cause lesions on leaves, twigs and trunks, although the relative rates of lesion developmentvarieddepending on the assay.

Table 4. Mean kauri seedling height increment $(\mathrm{mm})$ and feeder root disease scores, measured 4 months after soil inoculation with one of four Phytophthora species. Root disease was scored on a $0-5$ scale, where $0=$ less than $5 \%$ root tip decay, $1=5-25 \%, 2=25-50 \%, 3=50-75 \%$, $4=75-99 \%$ root tip decay and $5=$ dead. Letters in brackets indicate statistical significance groupings determined by Tukey's pairwise comparisons. Data not sharing a common letter are significantly different $(\mathrm{P}<0.05)$ from each other.

\begin{tabular}{lcc}
\hline Species & $\begin{array}{c}\text { Height } \\
\text { increment }\end{array}$ & $\begin{array}{c}\text { Root disease } \\
\text { score }\end{array}$ \\
\hline Control & $13.8(\mathrm{~A})$ & $0.58(\mathrm{~A})$ \\
P. cinnamomi & $15.4(\mathrm{~A})$ & $2.08(\mathrm{~B})$ \\
P. cryptogea & $14.3(\mathrm{~A})$ & $2.17(\mathrm{~B})$ \\
P. multivora & $14.5(\mathrm{~A})$ & $1.25(\mathrm{AB})$ \\
P. taxon Agathis & $2.8(\mathrm{~B})$ & $5.00(\mathrm{C})$ \\
(PTA) & & \\
\hline
\end{tabular}


When introduced into a wound, all three species were able to colonise and spread into healthy tissue and cause lesions. However, in inoculated trunks, lesion spread was in most cases limited, and when assessments were made 4 months after inoculation, none of the trunks was girdled and all trees remained healthy. One of the P. multivora isolates was obtained from a significant trunk lesion in a large kauri tree (Peter Scott, Scion, personal communication), suggesting that this species may be highly pathogenic. However, this isolate did not seem particularly aggressive in any of the present assays. All surviving trunk-inoculated trees have been retained in the glasshouse and monitoring will continue.

Phytophthora cinnamomi, P. cryptogea and P. multivora each caused significant feeder root damage when added to soil, although this was not reflected in reduced plant growth in the glasshouse assay. However, the $25-50 \%$ root damage observed could be very significant in a forest situation with other pathogens and environmental stresses. Although their pathogenicity is substantially less than that of PTA, P. cinnamomi, P. cryptogea and $P$. multivora have the potential to influence the health, growth and survival of kauri. Whether these other Phytophthora species exacerbate PTA problems in the forest is not yet known. PTA is such an aggressive pathogen of kauri that its presence alone in a kauri site is probably sufficient to cause decline and death. The presence of other Phytophthora species at such a site might perhaps worsen the problem, but relative to PTA they are likely to have little additional impact. Studies of these interactions are yet to be carried out.

\section{ACKNOWLEDGEMENTS}

This work was funded by Auckland Council. Thanks to Peter Scott from Scion for providing P. multivora isolates from kauri lesions.

\section{REFERENCES}

Beever RE, Waipara NW, Ramsfield TD, Dick MA, Horner IJ 2009. Kauri (Agathis australis) under threat from Phytophthora? In: Phytophthoras in Forests and Natural Ecosystems. Proceedings of the Fourth Meeting of IUFRO Working Party S07.02.09. General Technical report PSW-GTR-221, USDA Forest Service, Albany, CA, USA. Pp. 74-85.
Beever RE, Tsai S, Waipara NW, Dick MA, Ramsfield TD 2010. Pathogenicity of Phytophthora taxon Agathis (PTA). Fifth Meeting of the International Union of Forest Research Organisations (IUFRO) Working Party 7.02.09, Phytophthoras in Forests and Natural Ecosystems; March 2010. Rotorua, New Zealand. p. 2 (Abstract only).

Erwin DC, Ribeiro OK 1996. Phytophthora Diseases Worldwide. APS Press, The American Phytopathological Society, St Paul, Minnesota.

Horner IJ 1984. The role of Phytophthora cinnamomi and other fungal pathogens in the establishment of kauri and kahikatea. MSc thesis, University of Auckland.

Johnston PR, Horner IJ, Beever RE 2003. Phytophthora cinnamomi in New Zealand's indigenous forests. In: McComb JA, Hardy GE StJ, Tommerup IC ed. Phytophthora in Forests and Natural Ecosystems. Second International IUFRO working Party 7.02.09 Meeting. Albany, Western Australia, 30 Sept-5 Oct 2001. Murdoch University Print, Murdoch, Australia. Pp. 41-48.

Newhook FJ 1959. The association of Phytophthora spp with mortality of Pinus radiata and other conifers. New Zealand Journal of Agricultural Research 2: 808-843.

Podger FD, Newhook FJ 1971. Phytophthora cinnamomi in indigenous plant communities in New Zealand. New Zealand Journal of Botany 9: 625-638.

Scott PM, Burgess TI, Barber PA, Shearer BL, Stukely MJC, Hardy GE St J, Jung T 2009. Phytophthora multivora sp. nov., a new species recovered from declining Eucalyptus, Banksia, Agonis and other plant species in Western Australia. Persoonia 22: 1-13.

Waipara NW, Hill S, Hill LMW, Hough EG, Horner IJ. 2013. Surveillance methods to determine tree health, distribution of kauri dieback disease and associated pathogens. New Zealand Plant Protection 66: 235-241. 